\title{
Algunhas consideracións sobre os dativos non argumentais
}

\author{
María Luísa Pita Rubido \\ Servizo de Normalización Lingüística da \\ Universidade da Coruña
}

\begin{abstract}
Resumo:
Existe un grande caos para definir, delimitar e clasificar os que demos en chamar dativos non argumentais, aqueles elementos oracionais que non pertencen ao esquema actancial do verbo porque non veñen exixidos obrigatoriamente por este, mais que desempeñan sen ningunha dúbida unha función importante na configuración do enunciado. A súa similitude formal co tradicionalmente chamado complemento ou obxecto indirecto levou a confusións e interpretacións imprecisas, normalmente asentadas en criterios de carácter semántico, dando lugar a tipoloxías condicionadas polo contexto referencial máis que polos trazos formais que estes dativos posúen. A nosa intención neste breve artigo é a de dar conta de certos aspectos que nos parecen importantes para abordar unha caracterización e unha clasificación dos dativos non argumentais que se pretenda lingüisticamente obxectiva.
\end{abstract}

\section{Palabras chave:}

Dativos non argumentais, complemento ou obxecto indirecto, dativo de interese, dativo posesivo, dativo ético, dativo de solidariedade.

\begin{abstract}
:
We come across a lot of difficulties when we try to define, to delimit and to classify the socalled "non-argumentative dative prononus". These are those sentence elements that do not belong to the actantial verbal scheme because they are not compulsorily required by this. However, they play an important role within the configuration of a text.Its formal similarity with the traditionally called "indirect complement or object" led to misunderstanding or inaccurate interpretations. They are normally based on semantic criteria bringing about typologies conditioned by the referential context rather than by formal features of these dative prononus. Our intention in this brief article is to give account of the characterization and classification of non- argumentative dative pronouns. We will try to do it as objectively as possible from a lingüistic point of view.
\end{abstract}

Key words:

Non-argumentative datives, indirect complement datives, interest datives, possesive datives, ethical datives and solidarity ones. 


\section{Introdución}

A existencia duns elementos peculiares, de aspecto formal semellante ao do complemento indirecto mais con matices importantes que os diferencian deste, non pasou desapercibida para os gramáticos e estudosos da lingua ao longo da historia. En maior ou menor medida intentóuselles deixar un espazo nas descricións teóricas sobre as funcións sintácticas, ás veces considerándoos subtipos do propio complemento indirecto e noutras ocasións -na maior parte das ocasións- intentando deixar claro a súa pertenza a outra esfera, mais sen afondar no cerne da súa esencia. Así, achámonos fundamentalmente con definicións que se cinguen á explicación dos contextos en que se empregan ou no matiz semántico que se desprende deles, facendo clasificacións moitas veces confusas e que varían considerabelmente duns autores a outros.

No caso das gramáticas galegas o protagonista é sen dúbida o chamado dativo de solidariedade, xa que se considera un elemento especificamente galego ou, polo menos, característico da nosa lingua. Sobre a especificidade deste dativo falaremos tamén neste pequeno estudo.

A conclusión a que queremos chegar con esta reflexión é que as etiquetas de "dativo de interese", "dativo posesivo", "dativo ético" e "dativo de solidariedade" -entre outras-, que proliferan nos estudos gramaticais desde o principio dos tempos, non nos parecen demasiado acertadas nin axeitadas para estabeleceren unha tipoloxía, pois naceron do intento de clasificar estes elementos en base dun significado semántico de obxectividade dubidosa e determinado moitas veces por circunstancias de carácter contextual e non por trazos inherentes ao propio dativo.

A continuación intentaremos xustificar estas afirmacións que acabamos de facer e á súa vez propor unha clasificación de carácter formal en consecuencia cos nosos criterios.

\section{Clases de dativos non argumentais. $O$ peso da semántica nas tipoloxías tradicionais}

As diverxencias existentes entre as clasificacións realizadas polos autores que falaron sobre o tema son abundantes e debidas esencialmente ao seu carácter semántico que, ao teren a súa base nas distincións de significado orixinadas polo contexto en que se sitúa o dativo, poden recibir distintos matices que levan a distintas consideracións segundo o punto de vista que se adoptar. Este problema de "punto de vista" fai que as tipoloxías sexan subxectivas e varíen tanto no número de elementos considerados como na nomenclatura que recibe cada un dos tipos, ademais da adscrición de determinados exemplos a unha ou a outra clase de dativos. É moi fre- 
cuente que dativos incluídos en oracións semellantes merezan etiquetas diferentes segundo o autor que os analizar.

Como ben sinala Gutiérrez Ordóñez (1997: 143), unha boa parte dos traballos que analizan este tipo de elementos, por non dicir a maioría, baséase nas tipoloxías ofrecidas para o latín nas gramáticas de corte tradicional que intentan describir esta lingua, para así estabelecer unha clasificación adaptada ás linguas romances actuais sen ter en conta que os subgrupos delimitados no latín obedecen a unha necesidade de facilitar a tradución e comprensión da lingua clásica ao lector. Isto quere dicir que estas clasificacións non obedecen a criterios estritamente lingüísticos ou formais, senón que, como apunta Vázquez Rozas (1995: 56), teñen por obxecto daren conta da variedade referencial dos dativos e das distintas posibilidades parafrásticas das oracións que os conteñen.

Todo isto lévanos a considerarmos que non é sinxelo estabelecer unha tipoloxía para o conxunto de elementos que se sitúan baixo a etiqueta de dativo e que é difícil cinguirse a criterios estritamente lingüísticos en clasificacións desta índole, tan fundamentadas en relacións de tipo referencial ou extralingüístico. Vexamos algúns tipos de dativos que con frecuencia se distinguen nas gramáticas e as conclusións que se poden extraer das súas definicións.

Temos, en primeiro lugar, o denominado "dativo de interese". O seu nome estanos a indicar xa que o criterio que se segue para delimitalo e caracterizalo é totalmente semántico, obedece ao significado que desenvolve na oración, pois estímase que o seu valor nesta é o de designar a persoa que ten interese na realización da acción que denota o verbo porque dela obtén un determinado beneficio. Nalgunhas clasificacións precísase aínda máis e, segundo a consecuencia da acción levar consigo beneficio ou prexuízo, fálase de "dativo commodi" ou de "dativo incommodi". Vilela, por exemplo, fala de "proveito" e "detrimento", aínda que tamén lle atribúe outras significacións (Vilela 1992: 123). Para ilustrarmos estes dous tipos de dativos ofrecemos uns exemplos:

\section{Miña nai ordenoume o escritorio sen lle eu dicir nada (Dativo commodi).}

O can de Duarte roeume a camisa que tiña na cadeira (Dativo incommodi).

É obvio que a distinción que se fai é totalmente semántica e por tanto non nos parece moi axeitado facer diferenciacións deste tipo se quixermos obter unha clasificación obxectiva e estritamente lingüística. Formalmente trátase do mesmo dativo, pois funciona de igual modo nun caso que noutro e, de o considerarmos commodi ou incommodi, o único que estariamos a facer é deducir unha situación extralingüística que o enunciado non nos amosa realmente. Quere isto dicir que podemos supor que, no primeiro dos exemplos, o feito de que a nai do emisor lle ordene a 
este o seu escritorio é beneficioso para el, mais tamén pode ser que na realidade extralingüística esa acción non lle sexa proveitosa, ben porque iso supón unha organización das cousas de xeito diferente a como el/ela as quería etc. E o mesmo acontece co segundo exemplo, xa que, se á persoa que emite o enunciado non lle gustaba excesivamente a camisa de que está a falar, é probábel que a acción levada a cabo polo can lle resultase incluso beneficiosa.

A estas matizacións debemos engadirlle outra, e é que o dativo de interese, tal e como se formula, non ten por que estar circunscrito só ao ámbito do dativo non argumental. Con isto queremos dicir que mesmo pode deducirse no propio complemento ou obxecto indirecto tradicional esa noción de interese implícita. Vexamos os seguintes enunciados:

Uxío deulle a Sabela unha moeda de ouro (Complemento ou obxecto indirecto).

Uxío fixolle os deberes a Sabela (Dativo de interese).

Deste xeito pretendemos amosar a improdutividade do emprego deste tipo de etiquetas baseadas na semántica dos elementos da oración, cando menos para facermos unha clasificación, insistimos, obxectiva. Nos exemplos que acabamos de ver a única diferenza que se observa entre os dous lle e os dous a Sabela é a da súa pertenza ou non ao esquema actancial do verbo. Así, no primeiro caso, falamos precisamente de complemento ou obxecto indirecto porque este vén exixido na valencia verbal ('alguén dá algo a alguén') e, por tanto, desempeña unha función sintáctica dentro da oración. Porén, no segundo exemplo estamos ante un esquema diferente ('alguén fai algo') en que o dativo non figura como participante necesario. Podemos dicir que se trata, neste caso, dun elemento prescindíbel, mais iso non implica que o interese semántico que denota sexa maior ou menor que no caso do complemento indirecto e por iso non nos parece adecuada a denominación que adoita recibir.

Algo semellante acontece co chamado "dativo posesivo", que recibe ese nome porque se lle atribúe a función semántica de indicar posesividade substituíndo ou reforzando a presenza do determinante posesivo. Así, as seguintes oracións serían idénticas canto a significado, aínda que se poida falar de matices distintos en cada un dos casos (véxase Silva 1996: 242):

\section{Colleulle a man = Colleu $a$ súa man}

Debemos indicar que este tipo de dativo é empregado no galego non só con partes do corpo, senón tamén con nomes de parentesco e obxectos persoais, aínda que isto non pasa en todas as linguas (no francés só é posíbel con obxectos inalienábeis, 
como se pode ver en Silva 1996: 248), de xeito que nos atopariamos ante dativos posesivos en todos os casos semellantes aos seguintes:

\section{Colleulle a man (Colleu a súa man) \\ Morreulle o pai (Morreu o seu pai) \\ Rompéronlle a carteira (Romperon a súa carteira)}

Un dos argumentos que podemos manexar para refusar novamente esta distinción e delimitación do dativo posesivo é que, aínda que é perfectamente aceptábel a apreciación de que introduce un matiz semántico de posesividade, esa posesividade é tamén fundamentalmente extralinguiística e non é a única significación que podemos extraer dun enunciado que se constrúa mediante este dativo. Vexamos outros dous exemplos:

\section{Rompéronlle a carteira (Romperon a súa carteira)}

Rompéronlle a carteira da súa nai. (*Romperon a súa carteira da súa nai)

Obviamente non podémos falar de dativo posesivo no segundo caso e, no entanto, non parece existir unha diferenza substancial entre os clíticos das dúas oracións. Ademais, novamente a posesividade non é un trazo exclusivo dos dativos non argumentais, sendo posíbel atopala no complemento indirecto. Se substituírmos o verbo 'romper' polo verbo 'roubar', que exixe complemento indirecto no seu esquema actancial ('alguén rouba algo a alguén'), vemos que as cousas non mudan canto á semántica da forma de dativo:

\section{Roubáronlle a carteira (Roubáronlle a el a súa carteira)}

Deste xeito o complemento indirecto estaría a nos dar dúas informacións: quen é aquel a que lle roubaron a carteira e que relación tiña con esta, neste caso relación de posesión (lembremos que se trata de suposicións só comprobábeis na realidade extralingüística).

No caso dos dativos posesivos non argumentais tamén se poden apreciar matices semánticos distintos dos da posesividade, o cal nos levaría a incluír os mesmos exemplos en distintas categorías, de facermos unha clasificación tendo en conta as denominacións tradicionais para estes elementos. Volvamos ao exemplo de máis arriba:

\section{Rompéronlle a carteira}

Segundo o visto até o de agora, o clítico denota posesividade, mais non só iso, xa que é obvio que tamén se move na esfera do interese (dativo commodi ou incom- 
modi, segundo a realidade extralingüística a que se referir). $\mathrm{O}$ feito de que a carteira fose rota por alguén vai en proveito ou detrimento do afectado. A incoherencia e invalidez destas denominacións é, por tanto, evidente. Se un mesmo exemplo pode aparecer ligado á clase "dativos de interese" e á súa vez á clase "dativos posesivos" a rigorosidade das clasificacións que fan distinción entre ambos os tipos é cuestionábel.

Parécenos interesante mencionarmos a respecto do dativo posesivo a visión que Silva Domínguez ofrece sobre o tema e coa cal coincidimos plenamente (1996: 242-243). A súa proposta consiste en considerar o valor "posesivo" do dativo como un uso que, xunto con outros atribuíbeis a este elemento, constitúe tan só unha subespecificación dunha significación unitaria aplicábel a todo emprego do dativo:

[...] algúns traballos acerca dos clíticos do pronome persoal que renuncian a clasificar o tradicionalmente denominado "dativo posesivo" como unha categoría á parte dentro da tipoloxía de complementos verbais, e explican a maioría dos seus valores específicos a partir de factores pragmático-informativos e contextuais. En calquera caso, e independentemente de que esta sexa ou non a vía máis produtiva, parece necesario realizar unha tentativa de explicación unitaria dos valores do dativo que incluiría, desde logo, os seus supostos usos "posesivos".

Con esta afirmación, a autora parece deixar claro que dativo posesivo non constitúe unha clase diferenciada de por si, senón que esta "posesividade" funciona como valor contextual específico de determinadas manifestacións, valor circunscrito dentro doutro unitario común a todas as subespecificacións contextuais e situado nun nivel superior. Máis adiante Silva Domínguez (1996: 248-249) volve incidir neste aspecto:

Tamén problemática resulta a consideración funcional subxacente á etiqueta "dativo posesivo". Esta presupón un valor estable en lingua para determinado grupo de ocorrencias da forma pronominal átona, diferente do que posúe a mesma unidade noutras secuencias. Afírmase, xa que logo, a pertinencia na análise sintáctica funcional de etiquetas tradicionais como dativo posesivo, dativo de interese, dativo de separación etc., a pesar do seu evidente fundamento substancial. En calquera caso, antes de xebrar un conxunto de cláusulas con dativo do resto cómpre examinar a posibilidade de entender de xeito unitario a forma, desde unha única invariante de significado en coherencia coa súa invariancia formal. Se é posible demostrar que existe este valor unitario, ou máis ben se resulta inviable afirmar a entidade sintáctica destas distincións, o valor posesivo da forma dè dativo quedaría relegado ó ámbito inferencial, e non sería, pois, pertinente na descrición do sistema. 
A orixinalidade que, ao noso modo de ver, reside no traballo de Silva Domínguez, é debida á consideración de que os "dativos posesivos" reciben dentro do conxunto dos dativos (argumentais e non argumentais). Se até o momento estes eran vistos coma unha clase pechada e específica circunscrita fundamentalmente ao grupo dos dativos non argumentais (excepto en Álvarez / Regueira / Monteagudo 1986: 174), a autora obsérvaos dende un novo punto de vista situándoos nun nivel diferente. Esta idea que parece manterse como unha posibilidade ao longo de toda a súa análise, é corroborada finalmente coa seguinte conclusión:

Podemos, pois, considerar [...] o dativo posesivo como un valor contextual da unidade dependente tanto da semántica verbal como da ocorrencia simultánea de certo complemento de carácter "posuíble", e non estrictamente inalienable. O seu valor en lingua, independentemente de cal sexa a perspectiva que se escolla para definir este, é idéntico ó do resto das ocorrencias da forma (Silva Domínguez 1996: 257).

E máis adiante:

A análise lingüística do fenómeno non debería tentar xa a comparación de dúas estructuras sintácticas que alternan en función de diferentes factores, senón o exame, desde presupostos pragmáticos, das circunstancias comunicativas que permiten, nun momento dado, contemplar como innecesaria a aparición dunha unidade de significado explicitamente relacional como é o posesivo. Trataríase, pois, de decidir cando o contexto verbal e extraverbal proporcionan información dabondo para detectar a presencia do valor relacional que o posesivo indica de xeito explícito.

A notable variación patente entre todas as aproximacións á problemática do dativo, mesmo en temas tan importantes como a proposta de estatuto argumental ou periférico para os casos de dativo non rexido, non oculta a coincidencia case absoluta na idea de non dotar ó dativo posesivo dunha entidade diferenciada desde a perspectiva sintáctica. E isto é así porque a ocorrencia do pronome parece responder nestes casos ó mesmo principio semántico que se detecta no resto dos contextos en que aparece a unidade (Silva Domínguez 1996: 261).

Por tanto, podemos aplicar estas conclusións aos demais casos de dativo como serían o "dativo de dirección", o "dativo de relación", "o dativo de finalidade" etc. en que non nos imos deter aquí para non resultarmos redundantes. A idea fundamental é que existe unha fronteira moi fina, imperceptíbel, entre uns e outros, dado que se trata, insistimos, de denominacións que se desprenden de matices totalmente contextuais e, en todos os casos, estes trazos semánticos de dirección, relación, finalidade etc. son aplicábeis igualmente ao dativo argumental, é dicir, ao tradicionalmente denominado complemento ou obxecto indirecto. 
Un caso á parte configúrano os chamados "dativo ético" e "dativo de solidariedade". Aínda que as denominacións nos informan tamén sobre a asunción dun criterio semántico para a súa delimitación, nós consideramos que a diferenza fundamental entre estes dativos e os anteriormente tratados reside nunhas características formais que afastan uns dos outros. Máis alá do carácter "ético" ou "solidario" que se puider deducir nun enunciado pola inclusión destes elementos no seu interior, debemos ter en conta outros trazos que, a pouco que nos poñamos a analizar, non pasan desapercibidos. Estamos a falar, por un lado, da imposibilidade de desenvolver o clítico de dativo mediante unha construción introducida pola preposición $a$ no caso dos dativos ético e de solidariedade -trazo este que xa foi percibido por algúns autores como Alcina / Blecua (1975: 868) ou Porto Dapena (1992: 32-34) - e, por outro, da posibilidade de coexistencia con outros clíticos de dativo por parte tamén destes últimos, o que non parece ser posíbel nos complementos indirectos ou dativos de interese etc. É dicir, existen unhas características formais que xulgamos importantes, por non dicir decisivas, para diferenciarmos esta clase de dativos tanto do complemento indirecto como dos demais dativos, característica que nos pode axudar para chegarmos a coñecer cal é a diferenza esencial ou formal que se debe ter en conta para facer unha clasificación coherente.

Observemos os seguintes exemplos:

Miña nai ordenoume o escritorio sen lle eu dicir nada (Dativo de interese).

Non me lle deades caramelos ao neno (Dativo ético).

De intentarmos desenvolver unha construción introducida por a coa mesma función que o clítico de dativo, os resultados sería diverxentes dada a agramaticalidade da oración no caso do dativo ético:

Miña nai ordenoume a min o escritorio sen lle eu dicir nada (Dativo de interese).

*Non me lle deades a min caramelos ao neno (Dativo ético).

Aínda que falaremos máis adiante destes dativos "especiais" que só se manifestan a través de clíticos, adiantaremos agora que coidamos que esta peculiaridade é debida ao seu carácter "superfluo", que consideramos maior que no caso dos outros dativos non argumentais. Isto é consecuencia non só de que non veña exixido pola valencia do verbo, senón tamén de que, ademais, non introduza ningún novo participante no escenario da acción. No caso do dativo de interese, por exemplo, o clítico de dativo ou a construción con preposición engaden un elemento ao enunciado que, aínda que non o requira o verbo de xeito obrigatorio, matiza ou precisa a acción porque participa nela. Podemos dicir que a acción ten algunha influencia nese elemento satélite de que o emisor quere dar conta. No caso do dativo ético e do de solidariedade, como veremos, ese clítico desempeña un papel totalmente diferente porque non introduce ningún novo personaxe en escena simplemente 
inflúe na forma do enunciado, ficando restrinxido o seu papel á expresión da oración no momento en que esta se manifesta e non no contido enunciativo que se está a describir. A distinción 'dentro de escena' e 'fóra de escena' ou, en palabras de Maldonado (1998: 687-705), a 'distancia conceptual', é fundamental para distinguir uns dativos doutros e será baseándonos neste criterio principalmente que faremos a nosa proposta de clasificación.

Como acabamos de ver, as denominacións con que habitualmente se designan os dativos non argumentais teñen a súa razón de ser en explicacións de carácter semántico, extraídas da significación que un determinado clítico ou construción de dativo adquire nun contexto determinado. Aínda que este tipo de apreciacións semánticas é útil para interpretarmos determinados enunciados, non nos parece axeitado que se teñan en conta como criterio clasificador de dativos porque, como vimos, na maior parte dos casos os dativos non se diferencian entre eles formalmente e só desempeñan un papel determinado cando entran a formar parte dunha oración concreta referida a unha realidade extralingüística específica.

\section{Achegas para unha caracterización de base formal. Proposta de clasificación dos dativos}

Unha vez que desbotamos o criterio semántico e introducidos algúns aspectos en que imos basear a nosa proposta de clasificación dos dativos, imos dar paso á matización dalgunhas cuestións para clarificar a explicación da nosa visión sobre este tema.

Como dixemos máis arriba, os matices semánticos que amosan os dativos non argumentais nas oracións en que aparecen -imos deixar de lado por un momento os dativos ético e de solidariedade-son aplicábeis tamén na maior parte dos casos ao complemento indirecto. $\mathrm{O}$ interese, a posesividade, a dirección... son conceptos que emerxen nos enunciados segundo o contido destes e non se manifestan na oración mediante elementos formais distintos, senón sempre mediante clíticos de dativo ou estruturas introducidas pola preposición $a$. Simplificando, podemos dicir que o único que pode diferenciar estes elementos entre si é a súa obrigatoriedade ou non obrigatoriedade na oración, en canto que elementos exixidos ou non polo esquema actancial do verbo.

E en que se traduce esta obrigatoriedade ou non obrigatoriedade do dativo na oración? Pois certamente nunha distinción menos marcada do que adoitamos observar nas gramáticas. For ou non for argumental un dativo (é dicir, for complemento indirecto ou dativo de interese, posesivo etc.), o participante na acción que designa o dativo vese afectado por esta dalgún modo, aínda que non sexa de xeito tan directo como se o propio verbo exixise a súa presenza. Se complemento indirecto e dativo non argumental -exceptuando o ético e de o de solidariedade que, como vimos, eran casos especiais- introducen un participante na acción e formalmente se mani- 
festan do mesmo xeito (mediante clítico de dativo, construción con $a$ ou ambos), entón parece improdutivo trazarmos unha liña divisoria tan profunda entre eles, cando o único que os separa é a exixencia verbal. Se noutros casos non facemos distinción entre dous elementos semellantes formalmente por causa da súa valencialidade, parece pouco coherente que aquí si o fagamos. Por exemplo:

\section{Maruxa vai na Alemaña visitar os seus parentes}

\section{Maruxa mercou o coche na Alemaña para os seus parentes}

Como se pode observar, no primeiro caso estamos ante unha construción que sintacticamente denominamos complemento circunstancial de lugar e que sen dúbida vén exixida polo verbo $i r$. No segundo exemplo na Alemaña é un satélite, un elemento non valencial, mais que posúe as mesmas características que o anterior e que tamén indica lugar, considerándose por tanto tamén complemento circunstancial de lugar. Como vemos, aínda existindo esa diferenza de obrigatoriedade no esquema actancial, ninguén discute que nos dous casos estamos ante o mesmo tipo de construción, e este trazo non parece ser escusa para facermos tipoloxías que separen estes elementos en clases distintas.

Por que entón separar complemento indirecto e dativo? A nosa proposta pretende dar conta das diferenzas entre ambos mais restrinxíndoas ao trazo obrigatoriedadenon obrigatoriedade no esquema oracional como unha subdivisión de menor entidade que a existente entre este tipo de dativos argumentais e non argumentais e aqueles outros que se coñecen como dativo ético e dativo de solidariedade. A diferenza entre as clasificacións tradicionais (véxase, por citar un exemplo, Vilela 1992: 118-125, que distingue o complemento indirecto do dativo libre) e a nosa tipoloxía podería representarse esquematicamente do seguinte xeito:

\section{Clasificación prototípica habitual:}

\section{Obxecto ou complemento indirecto}

- Exixido pola valencia do verbo.

\section{Dativos non argumentais}

- Non exixidos pola valencia do verbo.

Dativo de interese.

Dativo posesivo.

Dativo commodi e incommodi.

Dativo ético.

Dativo de relación.

Dativo de finalidade. 


\section{Clasificación propia:}

\section{Obxecto ou complemento indirecto}

- Con posibilidade de redobro

\section{Dativo}

- Representado exclusivamente por clíticos.

$\begin{array}{lll}\text { Argumental } & \text { Non argumental } & \text { Sempre non argumentais } \\ \text { Tradicional } & \text { Tradicionais } & \text { Tradicionais dativo ético e } \\ \text { obxecto ou } & \text { dativos de interese, } & \text { dativo de solidariedade. } \\ \text { complemento } & \text { posesivo, } \\ \text { indirecto. } & \text { commodi e incommodi, } \\ & \text { etc. }\end{array}$

Como se pode observar, na nosa proposta optamos por denominar complemento ou obxecto indirecto tanto aos tradicionais complementos ou obxectos indirectos exixidos polas valencias verbais como aos dativos non argumentais de interese, posesivos etc. nomeadamente pola razón que antes apuntamos: a diferenza entre ambos é moito menor que a que existe a respecto dos dativos éticos e de solidariedade, para os cales si conservamos o nome de dativos por non designaren ningún "obxecto" participante na acción narrada. O feito de que non poidan desenvolverse mediante unha construción con $a$ impídenos considerármolos complementos ou obxectos indirectos, mais non ocorre o mesmo con aqueles dativos non argumentais que si permiten esta construción.

Unha cuestión que sería interesante tratar máis a fondo é a da denominación de "dativo" para os elementos que carecen de redobro. Sen dúbida escollemos este nome na nosa clasificación para os distinguirmos dos complementos ou obxectos indirectos e porque se trata dunha designación que tradicionalmente se empregou para estes clíticos. Porén, quizais esta denominación non sexa a máis axeitada porque non é paralela á de complemento ou obxecto indirecto e porque fai referencia a un antigo caso latino de que tanto estes elementos como os obxectos indirectos proveñen. Así, todos estes clíticos que estamos a analizar serían dativos -argumentais e non argumentais, con redobro e sen redobro- e non tería sentido reservar este nome só para unha clase concreta dentro dos mesmos. A dificultade de explicarmos mediante un termo a función destes elementos no enunciado fai que a procura dun novo nome para eles sexa unha tarefa arriscada que merecería un estudo máis profundo en que agora non nos imos deter. Do que si queremos deixar constancia é de que non consideramos pertinente facer unha subdivisión dentro desta clase de dativos fundamentada na persoa gramatical en que estes se manifestan. Para nós dativo ético e dativo de solidariedade son formalmente o mesmo dativo e máis adiante explicaremos en que nos baseamos para facer esta afirmación. 
A nosa proposta de clasificación fundaméntase, por tanto, nun criterio formal básico que é a aparencia que toma ou pode tomar o dativo na súa realización dentro da oración, aparencia que leva por tras unha razón de ser que analizaremos a seguir. Distinguimos, deste xeito, complementos indirectos e dativos -a falta dunha denominación máis acorde para estes elementos-, facendo á súa vez, no primeiro dos casos, unha subdivisión tendo en conta o carácter obrigatorio destes e obtendo así complementos indirectos argumentais e complementos indirectos non argumentais.

\section{Dativo ético e dativo de solidariedade. A aparición en escena dos xestores da mensaxe}

Queremos facer fincapé especialmente naqueles dativos "anómalos", no sentido de estes posuíren unhas características singulares que os afastan dos demais, e darmos unha explicación de por que se diferencian na súa natureza formal dos outros. Xa adiantamos antes, en certo modo, os motivos da imposibilidade de redobro mediante construción con preposición, mais procuraremos ir máis alá e cuestionármonos a división tradicional entre dativo ético e dativo de solidariedade, xa que consideramos que poden ser o mesmo tipo de dativo realizado mediante persoas gramaticais diferentes.

Outra idea que gustariamos de cuestionar é a que fai referencia á exclusividade da existencia do dativo de solidariedade na lingua galega, pois é posíbel achar no castelán coloquial e dialectal exemplos que dan conta de elementos semellantes a este -e non nos referimos aos casos tirados do castelán de Galiza onde o calco ou transvasamento de construcións tipicamente galegas é frecuente-. A respecto do portugués, parece que en xeral tamén se cuestiona a existencia deste fenómeno. Se observamos os exemplos que Figueiredo (1994: 267) ofrece para estes clíticos no galego e os comparamos coa tradución que fai para o portugués desas oracións (onde os clíticos son eliminados), podemos comprobar que o dativo de solidariedade se ve como algo estraño nesta última lingua:

Xa o ve, vostede, élle moi preguiceiro = Como o senhor pode ver, (ele) é muito preguiçoso

Entón, ímoslle indo = Então, vamos indo

\subsection{Peculiaridades e características dos dativos ético e de solidariedade}

Como dixemos máis arriba, o feito de que o complemento indirecto -argumental ou non argumental- poida manifestarse, ademais de a través de clíticos, mediante unha construción introducida por $a$, estanos a indicar que a súa función é a de dar conta dun personaxe ou dun elemento que participa na escena do que se está a 
representar, recibindo dalgún xeito e en maior ou menor medida as consecuencias da acción, ben sexan materiais, sentimentais, sensoriais, etc. Sexa o complemento indirecto argumental ou non, nunca fará referencia a un ente alleo ao que se nos está contando. Pola contra, non acontece o mesmo cos elementos a que nós restrinximos a denominación de dativo. A imposibilidade de se realizaren mediante unha construción de preposición apunta claramente á súa situación fóra de escena, á súa consideración de ente non participante na acción.

A quen fai referencia, por tanto, o dativo nestes casos? A pouco que observemos algúns exemplos, decatarémonos de que só é posíbel empregar a $\mathrm{P} 1$ e a $\mathrm{P} 2$ do pronome nestes casos, a P1 para o dativo tradicionalmente chamado ético e a P2 para o dativo denominado de solidariedade:

Non me estuda nada o cativo, non sei que facer del (Dativo ético, P1).

Éche ben lista, que aprobou todo en xuño e con boas notas (Dativo de solidariedade, P2).

De querermos reduplicar o dativo mediante unha construción introducida por $a$ observariamos que o resultado sería totalmente agramatical, a oración non acepta un novo participante na situación que se describe:

*Non me estuda nada a min o cativo, non sei que facer del (Dativo ético, P1).

* Éche ben lista a ti, que aprobou todo en xuño e con boas notas (Dativo de solidariedade, P2).

Que ocorre entón? Que eses elementos están claramente situados nun plano diferente ao da acción que se describe, non están inmiscidos nela como participantes, simplemente se colocan na oración para lle daren máis expresividade, para implicarse nela sentimentalmente, se queremos. Son uns elementos lingüísticos cunha significación menos transcendente para o enunciado, por dicilo dalgunha forma, porque se sitúan nun nivel máis superficial. Esquematicamente poderiamos representalo así:

$$
\begin{aligned}
& \text { Non }{ }^{\text {me }} \text { estuda nada o cativo, non sei que facer del. } \\
& E^{\text {che }} \text { ben lista, que aprobou todo en xuño e con boas notas. }
\end{aligned}
$$

Desta maneira estariamos ante uns elementos totalmente superfluos que non serían imprescindíbeis para a comprensión semántica do enunciado, o cal non acontecería no caso dos complementos indirectos, tanto argumentais como non argumen- 
tais. Nos exemplos que acabamos de ver a eliminación do dativo non suporía unha alteración na significación global da oración, aínda que poida significar unha diferenza no matiz de implicación sentimental do emisor ou do receptor. É por iso que na linguaxe formal, que non adoita facer concesións a trazos de carácter sentimental ou subxectivo, non se empregan estes dativos, só na linguaxe coloquial, máis propensa a introducir expresións que denotaren familiaridade ou achegamento entre os interlocutores. Vexamos o que acontece, no entanto, cos complementos indirectos:

Miña nai ordenoume o escritorio (Complemento indirecto non argumental) Miña nai ordenou o escritorio

Uxío deulle unha moeda de ouro (Complemento indirecto argumental) Uxío deu unha moeda de ouro

Tanto nun caso como no outro, de tirarmos o clítico, a cantidade de información vese reducida e só coñecemos parcialmente a realidade que se nos narra. Evidentemente no caso do complemento indirecto non argumental esa información pode parecer máis prescindíbel porque o ente a que fai referencia non vén exixido obrigatoriamente polo esquema actancial do verbo, mais sen dúbida a perda de información substancial é clara. Sabemos que se ordenou un escritorio e quen o fixo, mais sen a presenza do clítico non podemos coñecer de quen é o escritorio. E o mesmo acontecería co complemento indirecto argumental, sen a súa presenza non poderiamos coñecer o dato fundamental de quen foi o destinatario da moeda de ouro.

Esta é máis unha razón para considerarmos os dativos ético e de solidariedade como uns dativos especiais diferenciados claramente dos que nós demos en chamar complementos indirectos argumentais e non argumentais.

Outra característica que apuntabamos antes, e que tamén se relaciona coa exterioridade dos dativos con respecto da escena de acción, é a súa coocorrencia con outros clíticos de dativo. Quere dicir, os elementos para os cales nós reservamos a denominación de dativo poden combinarse con complementos indirectos tanto argumentais como non argumentais, ademais de con outros dativos da mesma clase, mentres que, pola contra, non poden aparecer varios complementos indirectos nunha mesma oración (si cos dativos mais, como veremos, debido a que son estes os que poden coocorrer cos demais elementos). Este comportamento lingüístico é bastante lóxico se temos en conta que os dativos e os complementos indirectos non se sitúan ao mesmo nivel en canto a "distancia conceptual" -en palabras de Maldonado (1998) - e por tanto non hai unha confluencia real de elementos dentro do enunciado. Cada un deles se sitúa nun plano, como xa dixemos. O que parece acontecer é que dous dativos no interior do mesmo escenario non poden mani- 
festarse porque desempeñarían un papel semellante e poderían ser confundidos entre si. Vexamos uns exemplos:

O neno de Uxía non che me come nada (dativo + dativo)

Roubáronchelle a carteira ao meu curmán (dativo + CI argumental)

*Fíxocheme a cea a ti a min (CI non argumental + CI argumental)

*Agarráronchelle a man a ti a Duarte (CI non argumental + CI non argumental)

Podemos observar que, de todas estas combinacións, só algunhas son posíbeis. No primeiro caso estariamos perante un dativo de solidariedade e outro ético (seguindo a nomenclatura tradicional) e o enunciado sería totalmente gramatical. No segundo dos exemplos acontecería o mesmo por ser un dos elementos un dativo. Porén, nos outros dous casos sería totalmente agramatical incluírmos dous complementos indirectos. No terceiro exemplo consideramos que un deles é non argumental porque entendemos que o significado da oración pode parafrasearse do seguinte xeito: Axudouche a facer a cea para min ou Fixo a cea que ti ías facer para min. No último exemplo estariamos perante dous dos tradicionalmente denominados dativos posesivos, non exixidos polo verbo mais si participantes da acción. Non debemos confundir o feito de que non poidan combinarse dous complementos indirectos con que non poida haber dous ou máis destinatarios da acción, simplemente entendemos que a copresenza de dous complementos indirectos non correferentes é imposíbel dentro dunha mesma oración. Obviamente unha mesma acción pode ter varios receptores, mais entón estes deben aparecer representados por un só complemento indirecto en plural, non por varios clíticos de dativo. Así, de querermos construír unha oración correcta lingüisticamente co significado que se sobreentende no último dos exemplos, deberiamos empregar outra estrutura:

\section{*Agarráronchelle a man a ti a Duarte - Agarráronvos a man a ti e a Duarte}

Podemos concluír, por tanto, que só habería un oco dentro do escenario da acción susceptíbel de ser cuberto por un complemento indirecto. Os dativos "superfluos", alleos a este escenario, uniríanse á oración como elementos externos ao enunciado e referidos a entes discursivos que non permitirían a confusión por ser engadidos $a$ posteriori. Deste xeito, ao pertencer a un nivel diferente, externo ao da acción en si mesma, non se produciría unha invasión do clítico na situación descrita pola oración, situación en que só sería posíbel a inclusión dun único dativo. Debemos afirmar, pois, que a posibilidade de coocorrencia de dous clíticos só é posíbel se un deles funciona no nivel discursivo. 


\subsection{Dativos diferentes ou o mesmo dativo? $O$ dativo de solidariedade e a súa circunscrición ao ámbito galego}

$\mathrm{Na}$ tradición gramatical adóitase tratar o dativo ético e o dativo de solidariedade como elementos diferenciados baseándose nunha suposta significación diferente e, por suposto, na exclusividade da persoa gramatical que se emprega con cada un deles, sendo atribuídos os clíticos de primeira persoa ao dativo ético e os de segun$\mathrm{da}$-ou terceira de cortesía, mais sempre en referencia ao interlocutor-ao dativo de solidariedade. Nós xulgamos que, o feito de que nas descricións gramaticais do español non se describa o dativo ético de segunda persoa -que consideramos equivalente ao noso dativo de solidariedade e que realmente si existe no español, como veremos- motivou a consideración de que o dativo ético só podía ser aquel que se desenvolvese mediante un clítico de $\mathrm{P} 1$. Por este motivo, cando os gramáticos galegos constataron a existencia dun dativo "superfluo" de P2 -ou P3 de cortesía, insistimos- non se "atreveron" a consideralo semellante ao dativo ético de P1 e describírono atribuíndolle trazos semánticos diferentes e unha denominación distinta. A orixinalidade e exclusividade deste dativo na lingua galega dábase por suposta até o punto de que autores como Saco Arce (1868: 165) afirmaban que a súa existencia era debida a unhas determinadas características psicolóxicas que se consideraban inherentes ao ser galego:

En el diálogo es frecuentísimo juntar al verbo el dativo del pronombre de segunda o tercera persona, (segun que se dé al tratamiento de $t i$ ó vostede al interlocutor), aunque á este no corresponda desempeñar ningun oficio directo ni indirecto en la oracion. Ejemplos: Cánta xente habia? Non che habia mais que dous homes. Cuanta gente habia? No más que dos hombres (literalm.: No te habia mas que dos hombres) [...] Este uso gramatical debe su orígen á la afabilidad del carácter gallego, que propende siempre á establecer cierta relacion de benevolencia ó cariño entre los interlocutores.

Nunha nota a pé de páxina engade:

Esta es la razon porque el que habla habitualmente en gallego, no pierde fácilmente este provincialismo, cuando quiere espresarse en castellano, pareciéndole indicio de sequedad ó despego la supresion de dicho dativo pronominal (Saco Arce 1868: 165)'.

A pesar da consideración do dativo de P2 como elemento característico do galego ao longo da historia dos nosos estudos gramaticais, parécenos innecesario e improdutivo facer distincións entre este clítico e o de P1. Non cabe dúbida de que non é o

1 Conservamos a ortografía orixinal do texto. 
mesmo introducir na oración o emisor que o receptor da mensaxe e de que os matices de significación poden variar, mais non máis alá da semántica, como acontecía nas gramáticas tradicionais para diferenciaren entre dativos de interese, dativos posesivos etc. Por iso mesmo non nos parece pertinente termos en conta esas diferenzas para facermos unha clasificación formal. Se vimos que o seu comportamento gramatical é o mesmo e que os dous se sitúan nun nivel distinto ao da acción narrada polo enunciado, temos argumentos suficientes para os considerarmos entes diferenciados. Parecen cumprir, sen ningunha dúbida, o mesmo papel comunicativo.

Unha obxección que se podería pór á consideración destes dous elementos como unha única realidade é, como mencionamos máis arriba, o feito de que no español, en principio, só se empregue a forma de P1, o chamado dativo ético. No entanto, aínda que non se describen nas gramáticas tradicionais, as formas de P2 aparecen dialectal e coloquialmente no español de Latinoamérica, como indica Maldonado (1998: 705). Isto fainos supor que, ou ben existiron estas formas nalgún momento da historia do español, ficando fosilizadas só no español de Ultramar, ou ben que só alí se desenvolveu por xeración espontánea ese tipo de dativo innovador na P2, ao igual que aconteceu no galego. Porén, que sexa máis frecuente a implicación do emisor que a do receptor nunha determinada lingua non nos parece razón suficiente para facermos distincións tipolóxicas cando, como xa dixemos, os dous dativos coinciden en todas as demais características formais. Vexamos algún exemplo do dativo ético de P2 no español:

\section{Te he dado unos buenos azotes al muchacho}

(Ordóñez 1997: 154)

¿Es cierto que te le arruinaron la vida a tu hija?

(Maldonado 1998: 705)

A simple vista poderiamos pensar que se trata de enunciados emitidos por unha persoa galega ao falar en castelán traspasando para esta lingua o dativo de solidariedade xa que, ao noso modo de ver, dativo ético de $\mathrm{P} 2$ e dativo de solidariedade son a mesma realidade con diferente denominación segundo a lingua en que aparezan. Non cabe a posibilidade de interpretar eses pronomes como participantes da acción que se narra, senón que fan referencia claramente ao receptor da mensaxe. Traduzamos os exemplos para o galego e veremos que non hai diferenza posíbel:

Déichelle unhas boas labazadas ao rapaz

É certo que che lle arruinaron a vida á túa filla? 
Non parece que haxa motivos para considerar este denominado dativo ético de P2 do español diferente ao noso dativo de solidariedade. $\mathrm{O}$ problema parece residir, por tanto, en que os nosos gramáticos atribuíron a unhas supostas características antropolóxicas do ser galego a aparición dun elemento linguístico que realmente debía a súa existencia e conservación ao feito de a lingua galega ser durante moitos séculos unha lingua circunscrita aos ámbitos familiares e coloquiais. Deste xeito podemos afirmar que aqueles xiros de índole marcadamente popular, como neste caso o dativo de solidariedade, se potenciarían de xeito máis acusado e máis xeral no galego que no castelán, dado que nesta última lingua a norma se estabelecería a través da escrita e, por tanto, dificultaría a aparición -ou, no caso de que xa existira, a súa conservación- de estruturas deste tipo. Por iso, unha estrutura idéntica nos dous idiomas pode ter o mesmo valor, mais sentirase como máis usual no galego, e de aí que a maioría dos autores a considerasen como particularidade exclusiva da nosa lingua.

Unha vez feita esta análise e rexeitando novamente denominacións de orixe semántica, coidamos que a mellor opción é designarmos estes clíticos de P1 e de P2 cun único termo, sen aludir a trazos de tipo semántico como a ética ou a solidariedade, que fan referencia a matices contextuais. Non obstante, somos conscientes de que a etiqueta dativo por que nós optamos non reflicte a especificidade destes elementos e, como xa dixemos máis arriba, deberiamos intentar achar un nome que se adecuase mellor ao concepto a que se refiren. De querermos adxectivar o nome de dativo para precisar máis un pouco a noción que del emerxe, xulgamos que a mellor opción sería a de considerármolos "dativos superfluos", "dativos expletivos" ou "dativos arbitrarios", como tamén se lles ten chamado nalgunha ocasión -Gutiérrez Ordóñez (1997), Álvarez (1997) e Longa / Lorenzo (2001) respectivamente-. Mediante esta etiqueta estamos dando a entender que son superfluos e prescindíbeis sen aludir á ética ou a solidariedade, sen dúbida subxectivas, do emisor e do receptor do enunciado.

Ora, máis alá dunha etiqueta ou dun nome que defina estes clíticos, queremos facer unha análise da súa significación e da súa razón de ser dentro da oración, xa que aparentemente non desempeñan un papel fundamental na significación do enunciado.

\subsection{Razón de ser dos dativos "superfluos" na oración}

Normalmente na descrición do dativo ético e do dativo de solidariedade fálase da implicación dos interlocutores no que se está a dicir ficando claro, pois, que se está a representar co dativo a persoa física que emite o enunciado e mais a aquela que o recibe. É dicir, estes dativos sitúanse nun nivel discursivo e fan referencia, por tanto, a aqueles elementos que se relacionan co acto da enunciación. Para definirmos a funcionalidade que teñen hai diferentes interpretacións. No caso do tradi- 
cional dativo ético é frecuente falar de que o seu papel é o de lle proporcionar á oración un matiz afectivo facendo referencia á persoa que se interesa especialmente na realización da acción. Algo parecido acontece co dativo de solidariedade, xa que as súas características principais pasan por implicar o interlocutor nos feitos que se narran e a que é alleo en tanto que participante (Freixeiro Mato 2000: 138). Tamén se alude a que a implicación do receptor ten como fin "provocar nel unha actitude ou resposta proclive ás posicións do emisor" (Álvarez / Xove 2002: 551).

De considerarmos que dativo ético e dativo de solidariedade son o mesmo tipo de dativo expresado por distintas persoas gramaticais porque fai referencia nuns casos ao emisor do enunciado e noutros casos ao receptor, sería lóxico procurarmos tamén unha explicación unitaria para describirmos o seu papel no discurso. Ao noso modo de ver, o feito de que se introduzan os xestores da información dentro da oración é unha fórmula de achegamento da situación narrada á realidade presente no momento da enunciación. Ao igual que na literatura se adoita chamar a atención do lector ou implicar o narrador para dar verosimilitude ao que se está a contar e para propiciar un achegamento entre a ficción e a realidade, así tamén o uso destes dativos favorece o contacto entre os dous mundos, o da acción narrada e o do contexto en que se emite o enunciado. Non cabe dúbida de que hai unha certa implicación sentimental, mais quizais non máis alá do puramente lingüístico e isto pode observarse no feito de que existan construcións con dativos deste tipo totalmente fosilizados. Observemos o seguinte exemplo:

\section{Lugo échevos a Pamplona de Galiza}

(adaptado de Álvarez 1997: 45)

Neste caso podemos observar que realmente existen dous dativos tradicionalmente chamados de solidariedade. Un deles, o que aparece subliñado, fai referencia a un receptor plural, polo que deducimos que o emisor está a falar con varios interlocutores. No entanto, aparécenos outro elemento que parece ter como finalidade realzar determinado matiz, o dativo que marcamos en negra e que non fai referencia directa aos interlocutores porque vai en singular.

A interpretación que podemos facer deste elemento inmobilizado na segunda persoa do singular é que a arbitrariedade deste tipo de dativos é tan alta que chega ao punto de que o receptor que se introduce no discurso non ten importancia como tal e de que a función orixinaria do clítico, que era a de chamar a atención do interlocutor para que se implicase no narrado, deixa de ter sentido. Pode dicirse que nestes casos existe un trazo funcional que adquire máis peso e que ese trazo se traduce na idea de achegar máis o que se di á situación comunicativa en que se emite o enunciado. 
Outro dato interesante que parece apoiar esta hipótese é o feito de que nas zonas teístas de Galiza se empregue, curiosamente, a forma che de xeito case exclusivo para o dativo de solidariedade e non a forma te esperábel que si aparece nos complementos indirectos (Álvarez 1997: 41-42). Isto indícanos que se perdeu a consciencia do dativo como referente do interlocutor, dado que non se emprega para designalo a forma que habitualmente se usa para os pronomes en "caso" dativo. A nova función que adquiriu o dativo discursivo, sexa cal for, vén xa de antigo, pois a forma ficou fosilizada cando aínda existía diferenciación formal entre os clíticos de dativo e os clíticos de acusativo nese territorio.

Xulgamos interesante citar neste punto o traballo de Longa / Lorenzo (2001: 176). Estes autores falan dun che arbitrario - "Arb CHE"- fixado na segunda persoa do singular que se identifica plenamente co dativo tradicionalmente chamado de solidariedade e que non se refire, segundo eles, ao receptor do enunciado, senón á situación indicada polo enunciado como un todo. O clítico expresa un interese arbitrario ou supraindividual, non real, como adoita considerarse na maioría das gramáticas.

Outra hipótese, que non invalida a anterior senón que a complementa, é a que relaciona este tipo de clíticos coas construcións impersoais. Así, nun traballo de Herslund (1988) fálase desta posibilidade. Este traballo, ao noso ver, achega datos moi interesantes para a interpretación do dativo ético de segunda persoa ou dativo de solidariedade que parece existir tamén no francés: Au Mont Saint-Michel, la mer te monte à une de ces vitesses! (1988: 278). Unha das observacións que Herslund realiza é a da relación que parece estabelecerse entre este tipo de dativos e a segunda persoa de carácter xenérico que podemos atopar en enunciados coma o seguinte:

Un type comme ça, il te donne sa chemise

'Un tipo así, dache a súa camisa'

(Herslund 1988: 278)

Nestes casos, a segunda persoa gramatical non se está a referir unicamente ao receptor da mensaxe en canto que tal nin tampouco a un afectado pola acción. A quen se apela mediante este procedemento (o do emprego da $\mathrm{P} 2$ xenérica) é a toda persoa que poida ter interese na situación narrada. A semellanza coas construcións impersoais parece evidente e así o fai notar tamén Herslund (1988: 277).

Ce qui est particulier à ces exemples, c'est que la deuxième personne ne réfère pas uniquement à l'interlocuteur, mais à toute personne susceptible de s'interesser à la situation décrite: c'est une deuxième personne générique, qui équivaut souvent à un on. 
Para o autor, será a intersección deste uso xenérico da P2 coa clase dos dativos clíticos sen estrutura preposicional a que dea lugar ao dativo ético, dado que en ambos os casos estamos ante pronomes que non xogan ningún papel na situación descrita na oración, mais que están implicados polo interlocutor na súa enunciación. Aínda que non se poida dicir que, por compartir estas características, nos achamos ante fenómenos idénticos, parécenos acertada a relación que neste traballo se estabelece entre dativos e segundas persoas xenéricas, e coidamos que ten especial importancia para o caso galego. O noso dativo de solidariedade parece en moitos casos remitir tamén a un ente abstracto que non sempre fai referencia exclusiva ao receptor da mensaxe.

A conclusión a que queremos chegar é que, aínda que o dativo faga realmente referencia ao emisor ou ao receptor da mensaxe empregando a persoa adecuada no número adecuado segundo a cantidade de interlocutores, a orixinaria función do dativo de implicar os xestores do discurso non é a única nin a fundamental destes clíticos. Existe un matiz que fai que haxa unha diferenza entre unha oración con presenza de dativo e outra idéntica mais sen clítico e que transforma a linguaxe do enunciado até o punto de resultar máis familiar ou coloquial cando se dá esa presenza do dativo. Ese matiz é obvio que ten a súa orixe no feito de implicar o que fala ou o que escoita nos feitos en que non participa mais, como vimos no caso da inmobilización na P2 do singular, o clítico de dativo pasou a funcionar como unha partícula que perdeu en boa medida o seu significado pronominal e que deixou en segundo plano a referencia externa ás persoas que participan no discurso. Trataríase de partículas cunha finalidade principal que sería a de daren carácter familiar á lingua empregada e a de acurtaren distancias entre o contado e o momento en que se conta.

\section{Conclusións}

De todo o dito aquí podemos facer unha breve recapitulación tendo en conta as ideas principais que quixemos destacar. A nosa intención era ofrecermos unha clasificación diferente ás tradicionais e, por tanto, que tivese a súa razón de ser en elementos obxectivos e estruturais ou formais, máis alá de interpretacións semánticas froito da análise de contextos significativos concretos. Para iso desbotamos aquelas nomenclaturas baseadas en trazos subxectivos como o interese, a posesividade, a ética ou a solidariedade e analizamos as características formais que os dativos presentaban ou podían presentar ao manifestárense na oración. Esta análise levounos a facer dous grandes grupos que designamos cos nomes de complemento indirecto e dativo respectivamente, mais que non coinciden co que na tradición gramatical se entende por complemento indirecto e dativo. Aínda que o nome destes elementos é discutíbel e pode ser ou non o máis axeitado, o que nos interesaba era deixar claro que a diferenza argumental-non argumental non nos parecía suficien- 
te nin principal para distinguir clases de dativos e que o importante era o grao de implicación do referente na acción descrita para poder estabelecermos distintos tipos. Como vimos, este grao de implicación maniféstase en realizacións formais distintas, pois nuns casos só é posíbel empregar o clítico e noutros é totalmente factíbel a presenza de construcións con $a$ á par do clítico ou incluso sen que este teña que aparecer.

No caso dos elementos que nós demos en chamar dativos non observamos diferenzas substanciais que nos fagan subdividir en clases diferentes aqueles que se realizan nunha persoal gramatical e aqueles que se realizan noutra. A razón de ser destes clíticos no discurso é a mesma e o feito de que nunhas linguas se empregue só o de P1 non nos parece motivo suficiente para afirmarmos que existen diferenzas formais nin funcionais.

\section{Referencias bibliográficas}

Alcina Franch, J. / Blecua, J. M. (1975): Gramática española (Barcelona: Ariel).

Álvarez, R. / Regueira X. L. / Monteagudo H. (1986): Gramática galega (Vigo: Galaxia).

Álvarez, R. (1997): "O complemento de solidariedade: a complicidade entre os interlocutores", en Actas do IV congreso internacional de estudios galegos: 37-53 (Oxford: Centro de Estudios Galegos).

Álvarez, R. / Xove, X. (2002): Gramática da lingua galega (Vigo: Galaxia).

Freixeiro Mato, X. R. (2000): Gramática da lingua galega. Vol. II. (Vigo: A Nosa Terra).

Figueiredo Silva, M. C. (1994): "Clíticos em galego: uma discussão dentro do quadro da teoria de regência e vinculação", en Lorenzo, R., Actas do XIX Congreso Internacional de Lingüística e Filoloxía Románicas. Tomo VI: 267-275 (A Coruña: Fundación Pedro Barrié de la Maza, Conde de Fenosa).

Gutiérrez Ordóñez, S. (1997): La oración y sus funciones (Madrid: Arco Libros).

Herslund, M. (1988): Le Datif en Français (París: Peeters).

Longa, V. M. / Lorenzo, G. (2001): “Universal constraints on 'superfluous'elements: The case of Galician 'Arb Che”,, en Gutiérrez-Rexach, J. / Silva-Villar, L., Current Issues in Spanish Syntax and Semantics: 175-191 (Berlín / Nova Iorque: Mouton de Gruyter).

Maldonado, R. (1998): "Datividad y distancia conceptual” en Cifuentes Honrubia, J. L. (ed.), Estudios de lingüística cognitiva. Vol. II: 687-705 (Alicante: Universidade de Alicante).

Porto Dapena, J. A. (1992): Complementos argumentales del verbo: directo, indirecto, suplemento y agente (Madrid: Arco Libros). 
Saco Arce, J. A. (1868): Gramática gallega (Lugo: Soto Freire).

Silva Domínguez, C. (1996): “A posesión inalienable: artigo, dativo, posesivo” en Lorenzo, R. / Álvarez, R. (coords.), Homenaxe á profersora Pilar Vázquez Cuesta: 241-263 (Santiago de Compostela: Universidade de Santiago de Compostela).

Vázquez Rozas, V. (1995): El complemento indirecto en español (Santiago de Compostela: Universidade de Santiago de Compostela).

Vilela, M. (1992): Gramática de valências: teoria e aplicação (Coimbra: Livraria Almedina). 